\title{
A study of process in psychoanalytic psychotherapy with children: the development of a method
}

\author{
Ana María Luzzi ${ }^{\circledR}$, Daniela Bardi ${ }^{1}$, Laura $\operatorname{Ramos}^{1}$, \& Sara Slapak ${ }^{2}$
}

\begin{abstract}
Objective: The aim of this article is to present the development of a method of analysis of the process of psychoanalytic psychotherapy with children (MAPPP-C) that is relevant for the study of the psychotherapy process from the perspective of the object relations theory. The process was studied by analysing changes in child patients' anxieties, defence mechanisms, object relations and unconscious phantasies, in each psychoanalytic psychotherapy session and throughout their entire psychotherapy. Method: MAPPP-C is both a qualitative and quantitative method of analysis of child psychoanalytic psychotherapy processes. This article will describe the stages in the development of the method, how the indicators were determined, the units of analysis in the study, the development of analytical codes, the training of raters in this method and inter-rater reliability and agreement tests. Results: This article describes the tasks that compose MAPPP-C, examples of its application and presents some hypotheses that arose from the analysis of the pilot study. Discussion: The preliminary results show that MAPPP-C is a method that allows one to assess the psychotherapist's interventions and the patient's responses in order to enable the analysis of the psychotherapeutic process. The results of the reliability test of the method will allow it to be applied to other types of psychoanalytic psychotherapy with both children and adults.
\end{abstract}

Keywords: method, psychoanalytical process, children

International scientific literature has shown a sustained interest in research about psychotherapeutic processes. The aims of this research are diverse and have been developed within different conceptual frameworks. Some focus on the study of verbal communication in patient-therapist interaction (Krause, 2011); others on the styles of the therapist (FernandezÁlvarez, Castañeira, Curtarelli, Garcia, Gomez, Lichtenberger \& Corbella. 2015), or on the level of libidinal development in patients through discourse analysis (Maldavsky, Argibay, De Simone, Perez Zambon, Plut, \& Stein, 2012), or on the verbal behaviour of the client (Ruiz-Sancho, Frojan-Parga, \& CaleroElvira, 2013), or on the relationship between generic

\footnotetext{
${ }^{1}$ Faculty of Psychology. University of Buenos Aires, Argentina ${ }^{2}$ University of Buenos Aires, Argentina

${ }^{\square}$ Correspondence author: Ana María Luzzi, SPR. Faculty of Psychology. University of Buenos Aires. Argentina; email to: aluzzi7@gmail.com
}

change indicators during the therapy process and the measuring of results (Krause, Altimir, Perez \& De la Parra, 2015).

Some empirical studies have used systems for coding clinical material which can be applied to different types of psychotherapy. Among these studies, it is worth mentioning the Therapeutic Activity Coding System (TACS-1.0) which was devised to enable the study of verbal activity of both patients and therapists as well as analyse change episodes during therapy (Valdés, Tomicic, Pérez \& Krause 2010). Other studies have used an observation and classification guide of therapists' verbal behaviour (ATOG-v) that can be applied to sessions with adult patients (Fernandez Alvarez et al., 2015).

Most of these studies used different methods of data collection and, even though their aims differed, they primarily focussed on verbal communication and, to a lesser extent, on material pertaining to non-verbal communication. 
There are fewer studies of processes in psychoanalytic psychotherapy with children than there are with adults. One of them is the Child Psychotherapy Process Q-Set (CPQ), an adaptation of the Psychotherapy Process (PQS; Jones, 2000), which is a technical scale consisting of items that make it possible to describe and classify the psychotherapy process with children. All of the material from one session can be analysed and used independently from the conceptual framework that guides the entire psychotherapy. Applying CPQ to the study of the psychotherapy process with children (Goodman et al., 2010) in items pertaining to the style of the therapist has made it possible to differentiate the dynamic psychotherapy process from the cognitivebehavioural psychotherapy process with children (Goodman, Midgley, \& Schneider, 2015).

Despite the existence of these and other previous publications regarding the study of the psychotherapy process with children, it still seemed interesting to devise a methodology, developed within the framework of Object Relations Theory (ORT), to specifically analyse the therapeutic changes that occur during the psychoanalytic process. It would involve the analysis of changes in child patients' anxieties, defence mechanisms, object relations and unconscious phantasies (Klein, 1932/1999, 1955/2004) in each psychoanalytic psychotherapy session and throughout the entire psychotherapy process. It would also entail analysing changes in the quantity and quality of the child patient's symbolic productions - verbalisations, games, drawings - and contrasting these changes with situations in which disturbances in the symbolic production become apparent- interruptions and acting outs, among others (Klein, 1932/1999, 1952/2004, 1957/2004).

Within the framework of ORT, psychoanalytic psychotherapy with children is carried out by using play technique. The child is given play and drawing materials which facilitate manifestations of phantasies, emotions and experiences (Klein, 1926/1999, 1927/1999). This means that the systematic study of clinical material must include the development and use of specific categories of analysis such as children's non-verbal manifestations - activities, gestures, onomatopoeia, playing and drawings, among others - as well as those that categorise verbalisations. It is also necessary to classify the child psychoanalyst's specific interventions.

This article will present the development of a method of analysis of the psychoanalytic psychotherapy process with children (MAPPP-C) which is relevant to the study of therapeutic change from the perspective of ORT.

\section{Method}

We will describe some aspects of the development of the method of analysis of the psychoanalytic psy- chotherapy process with children (MAPPP-C). We considered preliminary studies that have been carried out on other types of material, such as the $\mathrm{Di}$ agnostic Time Play (Aberastury, 1962) and the Free Drawing test (Wolff, 1962) in which common and differential indicators were devised to typify the psychopathologies of children in psychoanalytic psychotherapy treatment. We also used preliminary studies in monitoring protocols of psychoanalytic group therapy with children, which were created to determine therapeutic change and which had to be completed by the psychotherapist at the beginning of the treatment and no less than six months after the end of it. The indicators that were devised are the following: the child's relationship with the therapist, the child's relationship with his or her peers, the relationship of peers towards the child, games, drawings and verbal productions, and the continuity of the treatment (Slapak, Passalacqua, Cervone, Menestrina, Luzzi, Samaniego \& Berenstein, 2002).

Using these previous studies as a point of departure, we decided to undertake an empirical study of sessions and psychoanalytic psychotherapy processes with children in an attempt to deal with the discrepancies between how the psychotherapist perceived his or her interventions and what unfolded during the sessions, and what really happened. We decided to carry out a qualitative and quantitative analysis with the aid of ATLAS.ti software, which is known for facilitating the handling of big quantities of textual information, the segmentation of sessions, progressive coding and recoding, multiple coding of the same segment, and the search and retrieval of coded segments (Muñoz Justicia, 2005). This software, based on Glaser and Strauss's (1967) grounded theory approach, makes inductive theory building possible. The theoretical propositions are inferences that stem from empirical processes that are influenced by the theoretical training of the researcher.

Based on the indicators obtained through the analysis of the Diagnostic Time Play and the Free Drawing test, we drew up a list of provisional analytical codes or categories based on the corpus of ORT, specifically concepts pertaining to child psychoanalysis, and produced a glossary of their definitions.

The members of the research team carried out code assigning exercises by applying these codes to textual observational reports of sessions - the unit of analysis in the study - produced $a d$ hoc by nonparticipating observers. Each researcher split up the textual observational reports of the session into segments to which he or she assigned one or more codes taken from the provisional list and they also suggested new codes. The research team discussed these individual contributions: the codes and the segments to which they had been assigned were revised, recoding, reassigning and a frequency study of the assigned codes were carried out so as to enab- 

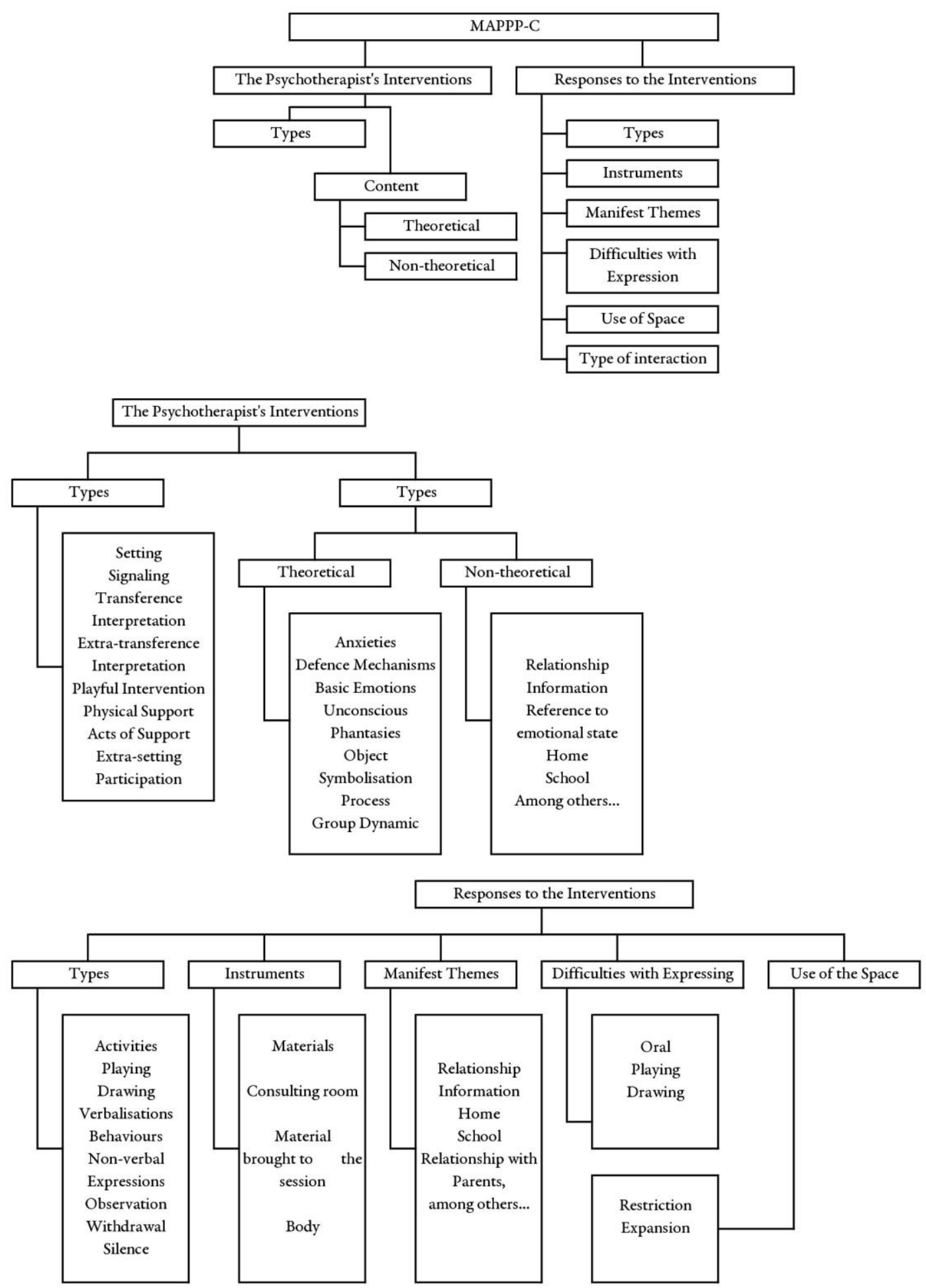

Figure 1. The MAPPP-C code families.

le the reformulation of the initial list of codes.

In the new version, the codes were organised hierarchically, grouped according to code families, and subcodes were created.

The definitions were improved and usage criteria were established. This final version was applied to different textual observational reports of individual and group psychoanalytic psychotherapy sessions with children so as to consolidate the method of analysis of the psychoanalytic psychotherapy process with child- 
ren (MAPPP-C). The method includes a Code Manual which contains the codes and their definitions as well as a Procedure Manual which is comprised of analysis and usage criteria.

In order to comply with the methodological requirement that entails carrying out inter-rater reliability and agreement tests, 6 independent researchers were trained in the code assigning tasks and assigned codes to 15 transcripts of individual psychoanalytic psychotherapy sessions with children and 10 transcripts of group psychoanalytic psychotherapy sessions with children. The statistical analysis of the results is currently underway so as to establish the reliability of the method.

\section{Results}

We will itemise the tasks that compose the MAPPP$\mathrm{C}$, provide an example of one aspect of its usage by applying it to a fictitious session segment, in compliance with confidentiality protection practices, and we will present some hypotheses that arose from the analysis of the pilot study which consisted of applying the MAPPP-C to nine psychoanalytic psychotherapy processes with children aged between 6 and 8 during a year of treatment.

\section{MAPPP-C}

MAPPP-C is both a qualitative and quantitative method of analysis of psychoanalytic psychotherapy processes with children which includes coding tasks, and the writing of memos and comments about material from psychotherapy sessions. At a later stage, the search and retrieval of information, and the calculation of the co-occurrence and frequency of the codes will allow one to follow the therapeutic changes of each patient throughout each session and the entire psychotherapy as well as study the relationship between these changes and the psychotherapist's interventions. The MAPPP-C can be applied to individual psychoanalytic psychotherapy and group psychoanalytic psychotherapy. In the latter case, it allows one to follow each individual patient and to notice interactions between peers, and with the psychotherapist. Coding is the basis of the qualitative analysis. One can understand how a way of reducing the information, given that each observational record of each one of the sessions represents such a large quantity of information, can be divided into quotations which can be assigned one or more codes. The code is not an interpretation of the material by the researcher, for even when the definition of the code refers to a theoretical concept its value is purely descriptive. The quotations can be extended accordingly, from one word or sentence to one or more paragraphs, or even the whole session.

In the manual the codes are grouped into two big code families: the psychotherapist's interventions and responses to the psychotherapist's interventions (figure 1). The manual includes a glossary with definitions of the analytical categories. As an example, the definitions that correspond to the "Types of Intervention" code family have been itemised (Table 1).

The "psychotherapist's interventions" code family corresponds to the psychotherapist's contributions, during the session, that aim to produce a therapeutic effect and that are in agreement with the clinical theoretical framework which includes the therapeutic setting. The decision to include the setting as a possible "type of intervention" is rooted in the theoreti cal framework, in which the spatio-temporal setting, the characteristics and the modalities of the psychotherapy, determined by the psychotherapist at the beginning of the psychotherapy and maintained throughout the treatment. It is, therefore, the intervention par excellence, for it, not only, gives meaning to, but also serves as the base of all the others (Bleger, 1967; Meltzer, 1967; Winnicott 1954/1975). The "psychotherapist's interventions" code family is comprised of different subfamily codes that further elaborate on these codes.

The "Responses to the interventions" code family corresponds to the patients' responses to the psychotherapist's interventions. It assumes that the child's verbalisations, activities, games, drawings and instances of acting out are always in response to the psychotherapist's interventions which can be understood within the framework of the "setting" determined by the psychotherapist at the beginning of the psychotherapy. Additionally, the following code families have also been included: Patients and Psychotherapists, which group together codes that allow one to differentiate and identify each patient and each psychotherapist, in compliance with confidentiality and ethical protection practices.

\section{The Psychotherapist's Interventions}

The Psychotherapist's interventions code family includes two subfamilies: Types of Intervention and The Content of the Interventions (Table 2).

Each intervention is coded according to the "Types of intervention", in agreement with the theoretical framework of a psychoanalytic psychotherapy, namely signaling, transference interpretation, extratransference interpretation, direct intervention, playful intervention, questions, instructions to the observer, acts of support and setting. There is also an extra-setting participation code which is applied to verbalisations or other contributions made by the psychotherapist which are not considered relevant within the technical theoretical framework (see the definitions of the types of intervention in Table 1). "The content of the interventions" made by the psychotherapist, which can be theoretical or nontheoretical, are also coded. The "theoretical content" 
Table 1. The Definitions of the Types of Intervention

\begin{tabular}{|c|c|}
\hline Code & Definition \\
\hline Setting & $\begin{array}{l}\text { It refers to all of the guidelines determined by the therapist } \\
\text { that aim to make the psychotherapy viable. It also includes } \\
\text { instructions, comments and the psychotherapist's actions } \\
\text { that indicate the rules of behaviour and that aim to } \\
\text { establish order when there is disengagement from or } \\
\text { transgression during the task. }\end{array}$ \\
\hline Signaling & $\begin{array}{l}\text { The therapist's description of a current individual or group } \\
\text { situation that makes clear manifest or observable aspects } \\
\text { that mainly refer to ego functions and emotional aspects of } \\
\text { the patient, at the time of the session. }\end{array}$ \\
\hline Transference Interpretation & $\begin{array}{l}\text { A therapist's verbal intervention regarding latent content } \\
\text { in the patient's manifestations. It refers to the revision of } \\
\text { initial object relations with the therapist at the time of the } \\
\text { session. It includes types of object relation, anxieties, } \\
\text { defence mechanisms and phantasies. }\end{array}$ \\
\hline Extra-transference Interpretation & $\begin{array}{l}\text { A therapist's verbal intervention, regarding latent content } \\
\text { in the patient's manifestations, from which reference to the } \\
\text { therapist as an object of transference (see transferential } \\
\text { interpretation) is excluded. }\end{array}$ \\
\hline Playful Intervention & $\begin{array}{l}\text { Acceptance on behalf of the therapist of roles assigned to } \\
\text { him or her by the patient. }\end{array}$ \\
\hline Physical Support & $\begin{array}{l}\text { The therapist's or observer's physical actions that aim to } \\
\text { control disruptive actions carried out by patients. }\end{array}$ \\
\hline Acts of Support & $\begin{array}{l}\text { The therapist's actions that maintain the child patient's } \\
\text { symbolic production. }\end{array}$ \\
\hline Extra-setting Participation & $\begin{array}{l}\text { The therapist's verbalisations that cannot be included in } \\
\text { the "types of intervention" code family because they are } \\
\text { not relevant to the technical theoretical framework. }\end{array}$ \\
\hline
\end{tabular}

of the interventions allude to the implicit hypotheses contained within the intervention and in agreement with the theoretical framework. These include the following subfamilies: anxieties, defence mechanisms, basic emotions, unconscious phantasies, group dynamics and processes of symbolisation. In turn, each of these subfamilies includes different codes, for example, the anxiety subfamily includes depressive anxiety and persecutory anxiety codes. The defence mechanism subfamily includes projective identification, manic defences, schizoid defences, denial codes, among others. The non-theoretical content from the interventions refers to manifest themes in the intervention, for example, school, home, extracurricular activities, among others.

In the context of group psychotherapy, it is necessary to differentiate "the receivers of the interventions" which means that for each intervention, as well as identifying its type, its theoretical content and its non-theoretical content, the person to whom the intervention is directed, be it the whole group or one or more patients in particular, is also indicated.

\section{Responses to the Psychotherapist's Interventions}

It includes six subfamilies: "Types of response" with the following codes: activities, playing, drawing, verbalisations, acting outs, silence, non-verbal expressions, observation and reserve; "Difficulties in expression" with the following codes: oral, playing and drawing; "Response instruments": means and resources used in the unfolding of activities, playing, drawing and acting out, with the following codes: materials from the games' box, objects from the office, materials not included in the games' box that the patients brought with them to the session and their bodies; "Manifest themes in responses": information about family relationships, home, school, among others; "Use of the space": expansive or restrictive; and "Types of interaction" which are descriptive terms, not necessarily theoretical ones: collaboration (the patient helps and cooperates with the therapist in achieving the aims of the treatment), deference (the patient carries out actions which are intended to please, satisfy and appease the therapist), curiosity (the patient shows an interest in knowing about the therapist's personal life), among others. In the context of group psychotherapy, it is necessary to differentiate the participants and the receivers of the responses.

\section{Memos and Comments}

They add depth to the coding work. The main purpose of the memos is to capture the analytical reflections 
of the researchers at each stage of the qualitative analysis. The researcher can use them when the conceptual categories, that allow him or her to analyse the material, are not sufficiently reflected in the codes (Ramos, Luzzi, \& Slapak, 2013). There are three types of memo:

a) Theoretical technical memos which are applied to the psychotherapist's interventions. They may contain an interpretational hypothesis concerning a segment of the patient's material that the research team may formulate when they believe that the psychotherapist's intervention regarding this material doesn't capture it in an adequate or relevant way according to the perspective of the theoretical corpus. For example, the research team

Table 2a. The application of the MAPPP-C to fictional clinical material

\begin{tabular}{|c|c|c|}
\hline \multicolumn{3}{|c|}{ FAMILY AND } \\
\hline QUOTATION & SUBFAMILY & CODE \\
\hline \multirow[t]{9}{*}{$\begin{array}{l}\text { M3 takes a doll from the } \\
\text { play box and handles it }\end{array}$} & Types of responses: & $\begin{array}{l}\text { Activity (Preparatory or exploratory action that organises the } \\
\text { field for a symbolic expression, that may or may not be carried } \\
\text { out) }\end{array}$ \\
\hline & Means or instrument: & Material from the toy box \\
\hline & Manifest Theme: & $\begin{array}{l}\text { (Not coded because it is a preparatory action whose theme is } \\
\text { not explicit) }\end{array}$ \\
\hline & Difficulties with Expressi- & (Not coded because no difficulties were recorded) \\
\hline & on: & \\
\hline & Use of space: & Restriction \\
\hline & Participant's response: & M3 \\
\hline & Receiver of the response: & (Not coded because the receiver was not explicit) \\
\hline & Type of interaction: & (Not coded because the interaction was not explicit) \\
\hline \multirow[t]{8}{*}{ V5 takes a lorry } & Types of responses: & Activity \\
\hline & Means or instrument: & Material from the toy box \\
\hline & Manifest Theme: & $\begin{array}{l}\text { (Not coded because it is a preparatory action whose theme is } \\
\text { not explicit) }\end{array}$ \\
\hline & $\begin{array}{l}\text { Difficulties with Expressi- } \\
\text { on: }\end{array}$ & (Not coded because no difficulties were recorded) \\
\hline & Use of space: & Restriction \\
\hline & Participant's response: & V5 \\
\hline & Receiver of the response: & (Not coded because the receiver was not explicit) \\
\hline & Type of interaction: & (Not coded because the interaction was not explicit) \\
\hline \multirow{8}{*}{$\begin{array}{l}\text { V2 reaches for V5's } \\
\text { building blocks }\end{array}$} & Types of responses: & Activity \\
\hline & Means or instrument: & Material \\
\hline & Manifest Theme: & $\begin{array}{l}\text { (Not coded because it is a preparatory action whose theme is } \\
\text { not explicit) }\end{array}$ \\
\hline & $\begin{array}{l}\text { Difficulties with Expressi- } \\
\text { on: }\end{array}$ & (Not coded because no difficulties were recorded) \\
\hline & Use of space: & Not relevant \\
\hline & Participant's response: & $V 2$ \\
\hline & Receiver of the response: & V5 \\
\hline & Type of interaction: & $\begin{array}{l}\text { Collaboration (The patient helps and cooperates with the } \\
\text { therapist in order to achieve the aims of the treatment) }\end{array}$ \\
\hline \multirow{8}{*}{$\begin{array}{l}\text { V5 puts some building } \\
\text { blocks in a line on the } \\
\text { desk to indicate that it is } \\
\text { a road and then drags } \\
\text { the lorry over it }\end{array}$} & Types of responses: & $\begin{array}{l}\text { Dramatic play (Play - symbolic expression of phantasies - in } \\
\text { which the patient plays characters and roles) }\end{array}$ \\
\hline & Means or instrument: & Material from the toy box; Body and Office \\
\hline & Manifest Theme: & Movement play \\
\hline & $\begin{array}{l}\text { Difficulties with Expressi- } \\
\text { on: }\end{array}$ & (Not coded because no difficulties were recorded) \\
\hline & Use of space: & Restriction (Limited and reduced use of the office space) \\
\hline & Participant's response: & VS \\
\hline & Receiver of the response: & (Not coded because the receiver was not explicit) \\
\hline & Type of interaction: & (Not coded because the interaction was not explicit) \\
\hline
\end{tabular}


Table $2 b$. The application of the MAPPP-C to fictional clinical material

\begin{tabular}{|c|c|c|}
\hline \multirow[t]{8}{*}{ V5: Rum, Rum } & Types of responses: & $\begin{array}{l}\text { Verbalisation: Onomatopoeia (Oral expression that reproduces the } \\
\text { sound of a thing or an animal that is accociated with dramatic } \\
\text { play). }\end{array}$ \\
\hline & Means or instrument: & Not relevant \\
\hline & Manifest Theme: & Movement play \\
\hline & Difficulties with Expression: & (Not coded because no difficulties were recorded) \\
\hline & Use of space: & Not relevant \\
\hline & Participant's response: & V5 \\
\hline & Receiver of the response: & (Not coded because the receiver was not explicit) \\
\hline & Type of interaction: & (Not coded because the interaction was not explicit) \\
\hline \multirow{8}{*}{$\begin{array}{l}\text { M3 takes cups, plates and } \\
\text { spoons, and feeds the doll }\end{array}$} & Types of responses: & Dramatic play \\
\hline & Means or instrument: & Material from the toy box \\
\hline & Manifest Theme: & $\begin{array}{l}\text { Bodily functions (Reference to normal and pathological bodily } \\
\text { functions, such as eating, dreaming, sphincter control, among } \\
\text { other) }\end{array}$ \\
\hline & Difficulties with Expression: & (Not coded because no difficulties were recorded) \\
\hline & Use of space: & Restriction \\
\hline & Participant's response: & M3 \\
\hline & Receiver of the response: & (Not coded because the receiver was not explicit) \\
\hline & Type of interaction: & (Not coded because the interaction was not explicit) \\
\hline \multirow[t]{8}{*}{$\begin{array}{l}\text { M1 and V4 are watching } \\
\text { what their peers are doing }\end{array}$} & Types of responses: & $\begin{array}{l}\text { Observation (An attitude that shows attentiveness with regards to } \\
\text { what is happening in the session) }\end{array}$ \\
\hline & Means or instrument: & Not relevant \\
\hline & Manifest Theme: & $\begin{array}{l}\text { (Not coded because it is a preparatory action whose theme is not } \\
\text { explicit) }\end{array}$ \\
\hline & Difficulties with Expression: & (Not coded because no difficulties were recorded) \\
\hline & Use of space: & Restriction \\
\hline & Participant's response: & $M 1, V 4$ \\
\hline & Receiver of the response: & $M 3, V 5$ \\
\hline & Type of interaction: & (Not coded because the interaction was not explicit) \\
\hline \multirow{4}{*}{$\begin{array}{l}\text { T1: V5 is playing a game } \\
\text { that boys usually play, } \\
\text { he's pretending to be a } \\
\text { father driving a car, while } \\
\text { M3 is playing live many } \\
\text { girls plays, she is a mother } \\
\text { feeding her children. M1 } \\
\text { and V4 are watching } \\
\text { them attentively }\end{array}$} & Type of intervention: & $\begin{array}{l}\text { Signaling (The therapist's description of a current individual or } \\
\text { group situation that makes explicit manifest or observable aspects } \\
\text { in the here and now of the session, mainly referring to ego func- } \\
\text { tions and emotional aspects of the patients.) }\end{array}$ \\
\hline & Content theoretical: & Identification, activity - passivity \\
\hline & Content non-theoretical: & Bodily functions, Movement play, Relationship with parents \\
\hline & $\begin{array}{l}\text { Receivers of the interventi- } \\
\text { on: }\end{array}$ & $V 5, M 3, M 1, V 4$ \\
\hline \multirow{8}{*}{$\begin{array}{l}\text { M3: This baby doesn't } \\
\text { want to eat. He says he is } \\
\text { full. }\end{array}$} & Types of responses: & $\begin{array}{l}\text { Manifestation of phantasies (Verbalisations that makes apparent } \\
\text { the relationship between internal objects -dramatisation-) }\end{array}$ \\
\hline & Means or instrument: & Not relevant \\
\hline & Manifest Theme: & Bodily functions \\
\hline & Difficulties with Expression: & (Not coded because no difficulties were recorded) \\
\hline & Use of space: & Restriction \\
\hline & Participant's response: & M3 \\
\hline & Receiver of the response: & $T 1$ \\
\hline & Type of interaction: & (Not coded because the interaction was not explicit) \\
\hline
\end{tabular}


Table 2c. The application of the MAPPP-C to fictional clinical material

\begin{tabular}{|c|c|c|}
\hline \multirow{8}{*}{$\begin{array}{l}\text { V5 throws the lorry on } \\
\text { the floor with force }\end{array}$} & Types of responses: & Acting out \\
\hline & Means or instrument: & Material \\
\hline & Manifest Theme: & Hostile \\
\hline & Difficulties with Expression: & (Not coded because no difficulties were recorded) \\
\hline & Use of space: & Expensive \\
\hline & Participant's response: & V5 \\
\hline & Receiver of the response: & M3 \\
\hline & Type of interaction: & (Not coded because the interaction was not explicit) \\
\hline \multirow{8}{*}{$\begin{array}{l}\text { V5: } \mathrm{He} / \text { she doesn't like } \\
\text { your food }\end{array}$} & Types of responses: & Manifestation of phantasies \\
\hline & Means or instrument: & Not relevant \\
\hline & Manifest Theme: & Bodily functions \\
\hline & Difficulties with Expression: & (Not coded because no difficulties were recorded) \\
\hline & Use of space: & Restriction \\
\hline & Participant's response: & V5 \\
\hline & Receiver of the response: & Directed towards M3 \\
\hline & Type of interaction: & Hostile, rejection \\
\hline \multirow{4}{*}{$\begin{array}{l}\text { T1: Suddenly something } \\
\text { happened. V5 threw the } \\
\text { lorry and M3 says the ba- } \\
\text { by doesnt't want to eat. } \\
\text { Something made you an- } \\
\text { gry, something frightened } \\
\text { you and you suddenly } \\
\text { stopped playing }\end{array}$} & Type of intervention: & Extra-transferential interpretation \\
\hline & Content theoretical: & Persecutory anxiety, partial bad object, Projective identification \\
\hline & Content non-theoretical: & Relationship with parents, Hostile \\
\hline & Receivers of the intervention: & $V 5 ; M 3$ \\
\hline
\end{tabular}

thinks that the therapist could have intervened by making explicit the use of certain defence mechanisms when dealing with certain anxieties in the studied session segment. These memos can also be applied to the "therapist's interventions" when the research team observe the presence of technical problems that affect quality, respect of relevance,

ways of formulating and opportunity, among others. For example, the psychotherapist's signaling is understood by the research team as being an instance of countertransferential acting out.

b) Methodological memos which communicate decisions made in agreement and put to the test in the research team's plenary meetings regarding the successive changes that have been made to the MAPPP-C. They allow the team to systematically record the building and modification of the method so as to make is easier for independent observers' to follow the development of the process of methodological revision.

c) Session dynamic memos which are applied to the totality of each session and reflect the main theme, or theoretical or technical aspects that were of particular interest to the research team. For example, "The theme that was present throughout the session was rivalry, jealousy, exclusion. It was expressed through a regulated game during which sudden changes and interruptions occurred".

Once the sessions have been coded, one can search and retrieve the different analytical categories used and the quotations of selected sessions. This paired with the retrieval of memos and comments, and the calculation of the frequency and co-occurrence of the codes used, complement and add depth to the qualitative analysis. It allows one to follow the changes in the patient's productions during each session and throughout the entire psychotherapeutic process and how they may relate to the psychotherapist's interventions.

\section{Example}

Below we will present the application of the MAPPP-C to fictional clinical material, intentionally produced to illustrate the application of the developed methodology. It is a fragment of a group psychoanalytic psychotherapy session with three boys and two girls aged 6 (Table 2).

This fragment attempts to show that in a brief segment of a session, the children can go from playing activities and games to acting out, that may or may not be accompanied by verbalisations and may or may not be shared. The possible effects of the 
psychotherapist's interventions are also exemplified here. In this case a first intervention - signaling sets in motion mental activities that lead to, in one case, the manifestation of fantasies (M3) and, in another, an instance of acting out (V5) that require an interpretation from the psychotherapist.

\section{Preliminary Results from a pilot study}

The preliminary results obtained have allowed the formulation of a hypothesis that, regardless of the differences in the therapists' levels of qualification and training, the formulations of both transference and extra-transference interpretations alike, when dealing with expressions of anxiety, correlate with progress in manifestations of patients' symbolic process and, therefore, a decrease in acting out.

In contrast, the "extra-framework" contributions (the therapist's contributions that are not relevant to the technical theoretical framework) and directive interventions (instructions or comments made by the therapist that guide the patient regarding rules of behaviour that are to be followed) correlate with an increase in acting out.

In the psychotherapeutic processes that were studied, we observed that in the first semester verbalisations predominated. These weren't generally expressions used to communicate but rather to offload. In the second semester, playing productions increased.

This allows us to formulate the hypothesis that, if there is a consensus in psychoanalytic literature (Klein, 1926/1999, 1932/1999; Winnicott, 1971) that playing constitutes a privileged form of expression and symbolic representation for children, playing is not a means but rather an end in the psychoanalytic psychotherapy process. This hypothesis is also related to research results that indicate a cooccurrence of the development of a child's ability to play during psychoanalytic psychotherapy, and the continuity and stability of the therapeutic setting. In contrast, children who have a lesser ability to play at the beginning of the psychotherapy, limit the quality of their productions when faced with a lack of continuity in the psychotherapy (Luzzi \& Bardi, 2010).

\section{Discussion}

The MAPPP-C makes it possible to carry out a thorough analysis of a patient's productions, to observe the progress and regression/relapses of each patient over the analysed period, in terms of more or less access to expressive resources that account for the process of symbolisation. Sudden changes in play, drawing and verbalisation production, correlated with disruptive acts or acting out, the characteristics and the variety of emotions and feelings at stake, the quality of the interactions with the therapist (and with peers in the case of group psychotherapy), the themes developed, are some of the cate- gories that were considered in order to evaluate the child psychoanalytical psychotherapy process.

The coding tasks makes it possible to access a view of a patient's psychotherapeutic process throughout a session and during the course of the psychotherapy, allow one to meticulously observe the patient's mental functioning in relation to the therapist's interventions now that a linear view has been achieved which allows one to "capture" and intensively analyse the processes.

The writing of memos and their later analysis brings tools to analyse the psychotherapist's duty. The systematic analysis of the technical theoretical memos allows one to evaluate the psychotherapists' theoretical level of knowledge and his or her ability to include that knowledge in the formulation of interventions that are in clear language and accessible to the receivers. It allows one to evaluate the distance that separates the theoretical frame-work that the psychotherapist assumes exists in his or her work and how it really works. It also makes possible the evaluation of the psychotherapist's shortcomings in terms of what the theory of the technique prescribes. It also gives us tools to reflect on the theory of the technique of interventions and puts the theoretical clinical hypotheses from the reference framework to the test, in the context of current psychoanalytic psychotherapy.

The methodological memos, not only, make it easier for independent observers to follow the development of the model, but also allow the research team to systematically revise their practices and understand that research implies arduous training in tolerating frustration, knowing that frequently it is necessary to "go back over" procedures and renounce obtaining quick results.

The qualitative analysis of the segments of the sessions allows one to compare interpretation styles and materials from different periods of a treatment, making it possible to shed light on some aspects that in clinical practice often go unnoticed.

The quantitative analysis, namely the calculation of the frequency and co-occurrence of the codes, allows one to examine in detail the relationship between the psychotherapist's interventions and the patient's responses, and eventually the psychotherapist's theoretical or technical shortcomings that may affect those responses. That is to say that it allows one to empirically observe how professional qualifications influence the trajectory or certain personal aspects over the course of the psychotherapeutic process. A by product of the application of MAPPP-C is its possible use in professional training as a complement to clinical supervision.

The preliminary results of the application of MAPPP-C to the pilot study, allowed us to develop hypotheses about the effects of the psychotherapist's different types of intervention in the patients' responses. While the transferential and extra-transferential 
interpretations point to the description of anxieties, defensive strategies and other unconscious aspects, they will also stimulate the symbolisation capacity of children's phantasies and impulses, mainly expressed through playing. The absence or scarcity of these kinds of interventions will, in contrast, be associated with the appearance of behaviours, expressed through disruptive or unexpected actions, that interrupt the symbolic processes.

The reliability study, currently underway, is an essential methodological requirement which will allow the application of MAPPP-C to be extended to different modalities of ORT child psychoanalytic psychotherapy: group psychotherapy, individual non focussed and or individual focussed. The necessary adaptations could be carried in order to enable its use in adult psychoanalytic psychotherapy. A reliable method for the study of psychoanalytic psychotherapy processes will allow the development of research in the therapeutic change in patients and the effectiveness of different psychotherapeutic strategies.

\section{References}

Aberastury, A. (1962). La primera hora de juego. En Teoría y Técnica del Psicoanálisis de Niños (108-130). Buenos Aires: Paidós.

Bleger, J. (1967). Psychoanalysis of the psycho analytical setting. Journal of Psychoanalysis, 24(2), 241-258.

Fernández-Álvarez, H., Castañeiras, C., Curtarelli, A., García, F., Gómez, B., Lichtenberger, A., \& Corbella, S. (2015). Presentación de una Guía para la Observación y Clasificación de la Conducta Verbal de los Terapeutas. Terapia psicológica, 33 (1), 23-34.

Glaser, B. S. \& Strauss, A. (1971). The discovery of grounded theory. New York.

Goodman, G. Midgley, N. \& Schneider C. (2015). Expert clinicians' prototypes of an ideal child treatment in psychodynamic and cognnitive-behaviour al therapy: is mentalization seen as a common process factor? Psychotherapy Research, doi: I10.1080/10503307.2015.1049672

Jones, E. (2000). Psychotherapy Process Q-set (PQS). Therapeutique Action. Northvale, New Jersey: Jason Aronson Inc.

Klein, M. (1999). The psychological principles of early analysis. (H. Friedenthal\& A. Aberastury, Trads.). In Love, guilt and reparation. Melanie Klein Complete Works (Vol. 1, pp. 137- 147). Buenos Aires: Ed. Paidós. (Original text published in 1926).

Klein, M. (1999). Symposium on child analysis. (H. Friedenthal\& A. Aberastury, Trads.). In Love, guilt and reparation. Melanie Klein Complete Works (Vol. 1, pp. 148-177) Buenos Aires: Ed. Paidós. (Original text published in 1927).

Klein, M. (1999).The Psycho-Analysis of Children. ( $\mathrm{H}$. Friedenthal\& A. Aberastury, Trads.). Vol. 2. Buenos Aires: Ed. Paidós. (Original text published in 1932).

Klein, M. (2004). The origins of transference. (V. S. of Campo, S. Dubcovsky, V. Fischman, H. Friedenthal, A. Koremblit, D. Liberman, R. Malfé, N. Rosenblatt, N. Watson \& S. Zysman, Trads.). In Envy and Gratitude. Melanie Klein Complete Works (Vol. 3, pp. 57- 65). Buenos Aires: Ed. Paidós. (Original text published in 1952).
Klein, M. (2004). The psycho-analyticplaytechnique: itshistory and significance. (V. S. of Campo, S. Dubcovsky, V. Fischman, H. Friedenthal, A. Koremblit, D. Liberman, R. Malfé, N. Rosenblatt, N. Watson \& S. Zysman, Trads.). In Envy and Gratitude. Melanie Klein Complete Works (Vol. 3, pp.129-146). Buenos Aires: Ed. Paidós. (Original text published in 1955).

Klein, M. (2004). Envy and Gratitude. (V. S. of Campo, S. Dubcovsky, V. Fischman, H. Friedenthal, A. Koremblit, D. Liberman, R. Malfé, N. Rosenblatt, N. Watson \& S. Zysman, Trads.). In Envy and Gratitude. Melanie Klein Complete Works (Vol. 3, pp.181-140). Buenos Aires: Ed. Paidós. (Original text published in 1957).

Krause, M., Altimir, C., Pérez, J.C., De la Parra, G., (2015). Generic change indicators in therapeutic processes with different outcomes. Psychotherapy Research, 25(5), 53345. doi: 10.1080/10503307.2014.935516.

Luzzi, A. \& Bardi, D. (2010). Playing Study in children under extreme psycho-social vulnerability conditions. In Trimboli, A., Fantin, J., Raggi, S., Fridman, P., Grande, E., Betran, G. (Eds.), Trauma, history and subjectivity (pp. 3940). Buenos Aires: Connections Series.

Maldavsky, D., Argibay, J. C., De Simone, L., Perez Zambón, S., Plut, S., \& Stein, E. (2012). Distribución de frecuencias de los deseos en las palabras de pacientes y terapeutas en psicoterapia. Un estudio con el diccionario computarizado del algoritmo David Liberman. Investigación psicológica, 17(2), 11-12.

Meltzer, D. (1967). The Psycho-Analytic Process. Heinemann.

Muñoz Justicia, J. (2005). Análisis de datos textuales con Atlas. ti 5. Recovered from http://psicologiasocial. uab. es/juan/index. php.

Ramos, L., Luzzi, A., \& Slapak, S. (2013). Research in Psychoanalysis. By-products of an empirical methodology to determine therapeutic efficacy. Paper presented at the Fifth International Congress of Psychology, November 2013. Buenos Aires, Argentina.

Ruiz-Sancho, E. M., Froján-Parga, M. X., \& Calero-Elvira, A. (2013). Análisis de la conducta verbal del cliente durante el proceso terapéutico. Anales de psicología, 29(3), 779-790.

Lapak, S., Passalacqua, A., Cervone, N., Menestrina, N., Luzzi, A. M., Samaniego, C. \& Berenstein, I. (2002). Psychic Change: technical and evaluation instruments applied children that carry out psychotherapy psychoanalytic group. Revista da Psicología da Vetor Editora, 3(1), 86-97.

Valdés, N., Tomicic, A., Pérez, J. C., \& Krause, M. (2010). Sistema de codificación. Revista Argentina de Clínica Psicológica, 19, 117-130.

Valdés, N., Krause, M., \& Álamo, N. (2011). ¿Qué dicen y cómo lo dicen?: análisis de la comunicación verbal de pacientes y terapeutas en episodios de cambio. Revista Argentina de Clínica Psicológica, 20 (1), 15-28.

Winnicott, D. W. (1971). Play and reality. London: Tavistock Press.

Winnicott, D. (1975). Metapsychological and clinical aspects of Regression. In Through Pediatrics to Psychoanalysis (pp. 377-398). London: Tavistock (Original text published in 1954).

Wolff, W. (1962) La Personalidad del niño en edad preescolar; el niño en busca de su yo. Bs. As.: Eudeba.

Submitted: September 2015

Accepted: October 2015

Published: December 2015 